\title{
Novel Adipokine Fibroblast Growth Factor 21 Is Increased in Rheumatoid Arthritis
}

\author{
H. HULEJOVÁ ${ }^{1}$, L. ANDRÉS CEREZO ${ }^{1}$, M. KUKLOVÁ ${ }^{1}$, O. PECHA ${ }^{2}$, T. VONDRÁČEK ${ }^{1}$, \\ K. PAVELKA ${ }^{1}$, J. VENCOVSKÝ ${ }^{1}$, M. HALUZÍK ${ }^{3}$, L. ŠENOLT ${ }^{1}$ \\ ${ }^{1}$ Department of Experimental and Clinical Rheumatology, Institute of Rheumatology, First Faculty \\ of Medicine, Charles University, Prague, ${ }^{2}$ Institute of Biophysics and Informatics, First Faculty of \\ Medicine, Charles University, Prague, ${ }^{3}$ Third Medical Department, First Faculty of Medicine, \\ Charles University and General Faculty Hospital, Prague, Czech Republic
}

Received January 23, 2012

Accepted June 18, 2012

On-line August 8, 2012

\begin{abstract}
Summary
Fibroblast growth factor-21 (FGF-21) has been recently characterized as a new adipokine. The aim of this study was to assess FGF-21 levels in patients with rheumatoid arthritis (RA) and osteoarthritis (OA) and to study the relationship between FGF-21, disease activity and metabolic status. The levels of FGF21 in serum and synovial fluid samples from 38 patients with RA and 42 control individuals with OA were determined by ELISA. Patients were assessed for disease activity using the disease activity score (DAS28), a serum glucose and lipid profile. Age, sex and BMI-adjusted FGF-21 levels in the serum $(p=0.024)$ and synovial fluid $(p=0.010)$ samples were significantly higher in patients with RA when compared with OA. The levels of FGF-21 in the serum significantly correlated with the levels in the synovial fluid. Serum and synovial fluid FGF-21 levels adjusted for confounders correlated positively with C-reactive protein. The levels of FGF-21 were positively correlated with BMI in patients with RA; however, the levels were not associated with disease activity or lipid profiles. Furthermore, serum FGF-21 levels were significantly higher in seropositive compared with seronegative RA patients. This work shows that patients with seropositive RA have increased levels of FGF-21. The results suggest that FGF-21 is related to BMI but not disease activity or lipid profiles in patients with RA.
\end{abstract}

\section{Key words}

Fibroblast growth factor-21 • Rheumatoid arthritis • Adipokines • Disease activity $\bullet$ Lipid profile

\author{
Corresponding author \\ Ladislav Šenolt, Institute of Rheumatology, $\mathrm{Na}$ Slupi 4, \\ 12850 Prague 2, Czech Republic. Fax: +420224914451. \\ E-mail: seno@revma.cz
}

\section{Introduction}

Osteoarthritis (OA) and rheumatoid arthritis (RA) are the two most common types of chronic joint disorders. OA is a complex degradative and repair process of cartilage and subchondral bone with a mild synovial inflammation. In general, OA is characterized as a degenerative disease associated with ageing; however, RA is a chronic inflammatory, autoimmune disease of unknown etiology that is characterized by progressive synovitis of the peripheral joints, followed by cartilage and bone destruction (Scott et al. 2010). Hyperplastic synovial cells and immune cells infiltrating the vascularrich synovial membrane produce a variety of proinflammatory cytokines that perpetuate inflammatory and destructive processes in the rheumatoid joint. Recent data demonstrated novel links between adipose tissue and rheumatoid arthritis (Derdemezis et al. 2011). Adipose tissue has emerged as a dynamic organ that not only stores energy but is also an important source of hormones and cytokines, generally known as adipokines. These adipokines have been shown to be associated with disease activity, inflammation and joint destruction in RA (Neumann et al. 2011, Ehling et al. 2006, Senolt et al. 2007, 2010, 2011a,b, Bokarewa et al. 2003). 
Fibroblast growth factor-21 (FGF-21), a member of the FGF super-family, has recently been identified as a potent metabolic regulator, leading to its characterization as a new adipokine (Kharitonenkov et al. 2005). The fibroblast growth factors are polypeptides with a wide range of biological functions, including cell growth, development, angiogenesis and wound healing (Beenken and Mohammadi 2009). FGF-21 has endocrine functions and, due to the lack of a conventional FGF heparinbinding domain, it is able to spread from its sites of origin to act as a hormone-like molecule. FGF-21 is predominantly expressed in the liver and, to a lesser extent, in adipose tissues, the pancreas, muscles and the testis (Dostálová et al. 2009). Previous reports demonstrated that FGF-21 functions as a regulator of glucose metabolism and lipid homeostasis. When administered to diabetic rodents and rhesus monkeys, FGF-21 improves several cardiovascular risk factors by decreasing blood glucose, triglycerides, LDL cholesterol and insulin levels and increasing HDL cholesterol levels (Kharitonenkov et al. 2005, 2007).

In contrast to animal models, there are fewer studies available on the role of FGF-21 in humans. FGF21 is elevated in the circulation of obese individuals and patients with type 2 diabetes mellitus (Mraz et al. 2009), metabolic syndrome, coronary heart disease (Lin et al. 2010), non-alcoholic fatty liver disease (Yilmaz et al. 2010) and Cushing's syndrome (Durovcová et al. 2010) as a consequence of postoperative inflammatory response (Kotulak et al. 2011). Additionally, the levels of FGF-21 are significantly reduced in patients with anorexia nervosa (Dostálová et al. 2008). Currently, there is lack of knowledge regarding the relationship between FGF-21 and inflammatory diseases. Very recently, FGF-21 has been shown to correlate positively with several factors, including CRP levels in patients with chronic kidney disease (Lin et al. 2011).

Because FGF-21 was proposed to be a new adipokine, it was of a great interest to examine whether FGF-21 is associated with RA, similar to what has been found with other adipokines.

\section{Patients and Methods}

Thirty eight patients with active RA (31 females and 7 males, mean age 59.97 \pm 2.23 ) fulfilling the American College of Rheumatology criteria for the classification of RA [21] and forty two control patients with OA (23 females, 19 males, mean age $64.05 \pm 1.54$ ) were enrolled in the study. This extended the study population from our previous work (Fojtíková et al. 2010). Individuals with diabetes mellitus and/or abnormal serum creatinine or renal disorder were not included in this study. The disease activity of the RA patients was assessed according to the 28-joint count disease activity score (DAS28) using the number of swollen and tender joints, CRP levels and the patient's global visual analogue scale (VAS). All patients gave informed consent, and the local ethics committee approved the study.

Synovial fluid was collected at the time of knee joint effusion that was part of a therapeutic regimen. Fasting blood was drawn up to 5 days after synovial fluid aspiration. Paired samples were immediately centrifuged, and both serum and synovial fluid samples were stored at $-80{ }^{\circ} \mathrm{C}$. Before analysis, synovial fluid samples were incubated with Hyase Dessau for $30 \mathrm{~min}$ at $37^{\circ} \mathrm{C}$.

The levels of FGF-21 in the serum and synovial fluid samples were measured by commercially available enzyme-linked immunosorbent assays (ELISAs) according to the manufacturer's protocol (BioVendor Laboratory Medicine, Inc., Modrice, Czech Republic). The assay was proven to be highly specific for human FGF-21, and it does not cross-react with other members of the FGF family. The assay detection limit was $7 \mathrm{pg} / \mathrm{ml}$, with intra-assay and inter-assay coefficients of variability of $3.0 \%$ and $3.9 \%$, respectively. Absorbance was detected using the Sunrise ELISA reader (Tecan, Salzburg, Austria) with $450 \mathrm{~nm}$ as the primary wavelength.

C-reactive protein (CRP) concentrations were assessed using turbidimetry, and erythrocyte sedimentation rates (ESR) were measured according to the protocol established by Fahraeus and Westergren. The levels of serum anti-citrullinated protein/peptide autoantibodies (ACPA) and IgM rheumatoid factor (IgMRF) were analysed by ELISA (Test Line s.r.o., Czech Republic). Serum lipids, including total cholesterol, highdensity lipoprotein (HDL) cholesterol, low-density lipoprotein (LDL) cholesterol, triglycerides (TG) and glucose, were assessed by standard methods (Beckman Coulter, Inc., Brea, CA, USA).

Data analysis was conducted using SPSS version 17.0 (SPSS, Inc., Chicago, IL, USA). The KolmogorovSmirnov test was used to evaluate normality. Comparisons between OA and RA groups were performed by two-sample t-tests and Mann-Whitney tests for normally and non-normally distributed parameters, 
respectively. The results were further adjusted for covariates (age, sex, and BMI) using one-way ANCOVA tests because of the imbalance of covariates between groups. Comparisons within both groups were performed by the Wilcoxon signed-rank tests. Correlations were assessed by Pearson product-moment correlation coefficients, and data were adjusted for age, sex and BMI using the partial correlation technique. The non-normal variables were correlated after logarithmic transformation. All values are expressed as mean \pm SEM. For each test, $\mathrm{p}<0.05$ was considered significant.

Table 1. Baseline characteristics of patients with rheumatoid arthritis or osteoarthritis.

\begin{tabular}{lll}
\hline & RA & OA \\
\hline $\begin{array}{l}\text { Number of patients } \\
\text { Mean age (years) }\end{array}$ & 38 & 42 \\
Gender (M/F) & $7 / 31$ & $64.05 \pm 1.54$ \\
BMI $\left(\mathrm{kg} / \mathrm{m}^{2}\right)$ & $25.19 \pm 0.63$ & $19 / 23$ \\
DAS 28 & $5.03 \pm 0.25$ & - \\
CRP (mg/l) & $22.76 \pm 3.86$ & $5.24 \pm 1.81$ \\
Total cholesterol & $5.88 \pm 0.26$ & $5.99 \pm 0.24$ \\
(mmol/l) & & \\
HDL cholesterol & $1.51 \pm 0.09$ & $1.25 \pm 0.07$ \\
(mmol/l) & & \\
LDL cholesterol & $3.80 \pm 0.19$ & $3.97 \pm 0.22$ \\
(mmol/l) & $1.26 \pm 0.11$ & $1.71 \pm 0.17$ \\
TG (mmol/l) & $5.71 \pm 1.59$ & $5.64 \pm 0.85$ \\
Glucose (mmol/l) & $0 \% \%$ \\
RF and ACPA positive & $55 \%$ & $0 \%$ \\
\hline
\end{tabular}

$M$, male; F, female; DAS28, disease activity score; CRP, C-reactive protein; BMI, body mass index; $\mathrm{HDL}$, high-density lipoprotein cholesterol; LDL, low-density lipoprotein cholesterol; TG, triglycerides; RF, rheumatoid factor; ACPA, anti-citrullinated protein/peptide autoantibodies

\section{Results}

Baseline characteristics of the study individuals are shown in Table 1. In general, the group of patients with RA had active disease (mean \pm SEM DAS28: $5.03 \pm 0.25)$. These patients had comparable age, total cholesterol, LDL-cholesterol and TG with the OA patients. However, in agreement with the increased prevalence of RA in women, the RA patients had lower BMI and higher CRP levels than the OA patients. Because of this bias, the FGF-21 levels were adjusted for age, sex and BMI. Lipid profiles were available from
26 patients with RA and from 34 patients with OA. In all but one patient, RA was treated with disease-modifying anti-rheumatic drugs. The majority of the patients received methotrexate $(n=28$, mean dose: $13.8 \mathrm{mg}$ per week; range: $7.5-25 \mathrm{mg}), 8$ patients received sulphasalazine, 5 received leflunomide, 26 patients received glucocorticoids (mean daily dose: $7.5 \mathrm{mg}$; range: 2.5-20 $\mathrm{mg} / \mathrm{d}$ of prednisone or equivalent) and nine patients were treated with biologics.

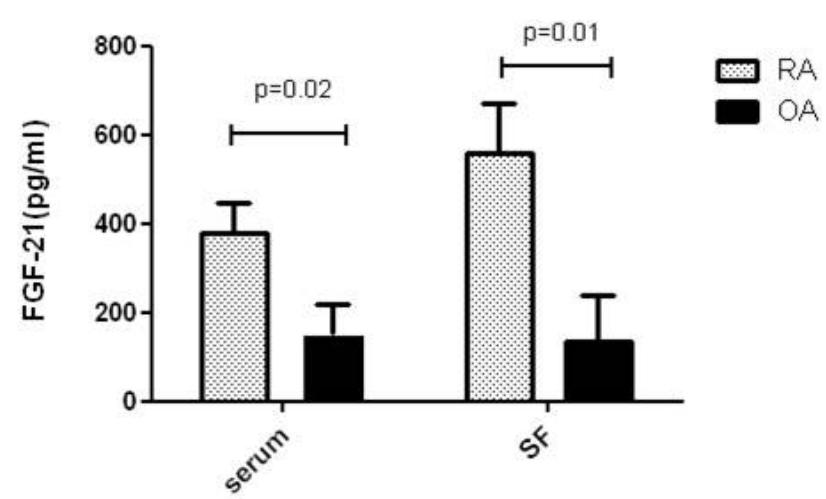

Fig. 1. The levels of FGF-21 after adjusting for age, sex and BMI in serum and synovial fluid (SF) samples from patients with rheumatoid arthritis or osteoarthritis.

To investigate the role of FGF-21 in inflammation and autoimmunity, we compared the levels of FGF-21 in serum and synovial fluid samples from 38 patients with RA and 42 control individuals with OA. The levels of FGF-21 in the subjects in this study ranged from 25.0 to $3129.8 \mathrm{pg} / \mathrm{ml}$ in the serum samples and from 15.0 to $4996.2 \mathrm{pg} / \mathrm{ml}$ in the synovial fluid samples. There were no sex differences in FGF-21 levels (serum: $254.05 \pm 78.25$ and $267.09 \pm 54.30 \mathrm{pg} / \mathrm{ml} ; \mathrm{p}=0.307$, synovial fluid: $404.18 \pm 135.90$ and $304.47 \pm 91.45 \mathrm{pg} / \mathrm{ml}$; $\mathrm{p}=0.181)$. After adjusting for age, sex and BMI, serum (378.87 \pm 66.81 vs. $155.80 \pm 64.10 \mathrm{pg} / \mathrm{ml} ; \mathrm{p}=0.024)$ as well as synovial fluid $(558.01 \pm 111.61$ vs. $135.30 \pm 105.35$ $\mathrm{pg} / \mathrm{ml} ; \mathrm{p}=0.010)$ levels of FGF-21 were significantly higher in patients with RA when compared with patients with OA (Fig. 1). FGF-21 levels did not significantly differ between synovial fluid and serum samples in either group of patients. The log-transformed levels of FGF-21 in the serum samples also significantly correlated with the levels in the synovial fluid samples in patients with RA $(\mathrm{r}=0.696, \mathrm{p}<0.001)$ and OA $(\mathrm{r}=0.645, \mathrm{p}<0.001)$. Although the levels of FGF-21 were not related to age or disease duration, the serum and synovial fluid levels of FGF-21 were positively associated with BMI in patients with RA ( $\mathrm{r}=0.400, \mathrm{p}=0.013$ and $\mathrm{r}=426, \mathrm{p}=0.010)$. 
However, this was not the case in patients with OA $(\mathrm{r}=0.092, \mathrm{p}=0.568$ and $\mathrm{r}=0.262, \mathrm{p}=0.103)$. Although we observed no association of serum and synovial fluid levels of FGF-21 with ACPA or IgM-RF antibodies, serum levels of FGF-21 were significantly higher in RA patients positive for both ACPA and IgM-RF compared to seronegative RA patients $(634.1 \pm 737.0 \quad$ vs. $173.3 \pm 139.2 \mathrm{pg} / \mathrm{ml} ; \mathrm{p}=0.030)$. However, this difference was not observed for FGF-21 synovial fluid levels.

After adjusting for age, sex and BMI, the serum $(\mathrm{r}=0.269, \mathrm{p}=0.023)$ and synovial fluid $(\mathrm{r}=0.261, \mathrm{p}=0.029)$ levels of $\log$ FGF-21 were significantly correlated with CRP levels in all subjects in this study. However, when the RA and OA patients were examined separately, this correlation disappeared. Furthermore, serum and synovial fluid FGF-21 levels that were adjusted for age, sex and BMI were not associated with disease activity, as assessed by DAS28 $(\mathrm{r}=0.032, \mathrm{p}=0.855$ and $\mathrm{r}=0.014$, $\mathrm{p}=0.939$, respectively). Surprisingly, we did not observe a correlation between the log-transformed levels of FGF-21 (even when adjusted for age, sex and BMI) and lipid parameters, including cholesterol, HDL cholesterol, LDL cholesterol, TG and glucose. Furthermore, the mean dose of glucocorticoids did not correlate with the levels of FGF-21 in either serum or synovial fluid samples (data not shown). Serum glucose levels between RA and OA patients did not significantly differ.

\section{Discussion}

These results are the first demonstration that the FGF-21 adipokine levels in the blood and synovial fluid of patients with RA are higher than in control individuals with OA. Furthermore, in patients with RA, the levels of FGF-21 were related to BMI and not to disease activity or lipid profile.

Many human studies over the past 10 years demonstrated than patients with RA have elevated levels of several adipokines, and these adipokines play a significant role in RA (Neumann et al. 2011, Ehling et al. 2006, Senolt et al. 2007, 2010, 2011a,b, Bokarewa et al. 2003). Recent data demonstrated that adipokines may reflect disease activity and may play an important role in modulating inflammation and joint destruction in RA. Here, we show significant increases in the levels of the new adipokine, FGF-21, in serum and synovial fluid samples from patients with RA when compared with control individuals with $\mathrm{OA}$. In contrast to the resistin and visfatin adipokines, the levels of FGF-21 in the synovial fluid, however, did not exceed the levels present in serum. This finding indicates that FGF-21 is produced systemically rather than at the site of local inflammation. This is consistent with results showing that FGF-21 is produced mainly in the liver and, to a lesser extent, in adipose and other tissues (Dostálová et al. 2009). However, there were previously no available data regarding the local expression of FGF-21 in RA synovial tissues that could fully support this hypothesis.

Our data do not show associations between serum and synovial fluid FGF-21 levels with laboratory or clinical markers of RA disease activity. This is consistent with a recent report showing no association between serum FGF-21 levels and CRP levels in patients undergoing cardiac surgery (Kotulak et al. 2011). However, our results conflict with the study showing an association between serum FGF-21 levels and CRP levels in patients with chronic kidney disease (Lin et al. 2011). Although we observed a positive correlation between serum FGF-21 levels and CRP levels in all studied subjects, this association could be explained by BMI because the association vanished when FGF-21 levels were adjusted for BMI. Although the FGF-21 levels were positively related to obesity and an adverse lipid profile (Dostálová et al. 2009, Mraz et al. 2009, Lin et al. 2010, 2011), patients with OA, who had higher weight, experienced with significantly lower levels of FGF-21 than those with RA. Furthermore, we did not observe an association between FGF-21 levels and lipid profiles in this study, although only some of the patients in this study had an available lipid profile. These data, however, suggest that other mechanism(s) may be implicated in the synthesis of FGF-21 during inflammation and immune responses. Furthermore, FGF-21 levels were higher in RA patients positive for RF and ACPA antibodies compared with seronegative RA patients. We hypothesize that the increase of FGF-21 in seropositive patients with RA may indicate a compensatory response to inflammation, immune response and/or to the increased incidence of metabolic syndrome and cardiovascular diseases in RA patients (McCarey and Sturrock 2009).

In conclusion, our study provides the first evidence of increased levels of FGF-21 in the serum and synovial fluid of patients with RA, particularly in seropositive disease. More studies are necessary to find the source of the elevated FGF-21 levels in RA patients and to better understand the exact role of FGF-21 in inflammatory and immune-mediated diseases. 


\section{Conflict of Interest}

There is no conflict of interest.

\section{Acknowledgements}

This study was supported by MHCR Research Project No. 00023728.

\section{References}

ARNETT FC, EDWORTHY SM, BLOCH DA, MCSHANE DJ, FRIES JF, COOPER NS, HEALEY LA, KAPLAN SR, LIANG MH, LUTHRA HS, ET AL.: The American Rheumatism Association 1987 revised criteria for the classification of rheumatoid arthritis. Arthritis Rheum 31: 315-324, 1988.

BEENKEN A, MOHAMMADI M: The FGF family: biology, pathophysiology and therapy. Nat Rev Drug Discov 8: 235-253, 2009.

BOKAREWA M, BOKAREW D, HULTGREN O, TARKOWSKI A: Leptin consumption in the inflamed joints of patients with rheumatoid arthritis. Ann Rheum Dis 62: 952-956, 2003.

DERDEMEZIS CS, VOULGARI PV, DROSOS AA, KIORTSIS DN: Obesity, adipose tissue and rheumatoid arthritis: coincidence or more complex relationship? Clin Exp Rheumatol 29: 712-727, 2011.

DOSTÁlOVÁ I, KAVÁLKOVÁ P, HALUZÍKOVÁ D, LACINOVÁ Z, MRÁZ M, PAPEZOVÁ H, HALUZÍK M: Plasma concentrations of fibroblast growth factors 19 and 21 in patients with anorexia nervosa. $J$ Clin Endocrinol Metab 93: 3627-3632, 2008.

DOSTÁLOVÁ I, HALUZÍKOVÁ D, HALUZÍK M: Fibroblast growth factor 21: a novel metabolic regulator with potential therapeutic properties in obesity/type 2 diabetes mellitus. Physiol Res 58: 1-7, 2009.

DUROVCOVÁ V, MAREK J, HÁNA V, MATOULEK M, ZIKÁN V, HALUZÍKOVÁ D, KAVÁLKOVÁ P, LACINOVÁ Z, KRSEK M, HALUZÍK M: Plasma concentrations of fibroblast growth factors 21 and 19 in patients with Cushing's syndrome. Physiol Res 59: 415-422, 2010.

EHLING A, SCHÄFFLER A, HERFARTH H, TARNER IH, ANDERS S, DISTLER O, PAUL G, DISTLER J, GAY S, SCHÖLMERICH J, NEUMANN E, MÜLLER-LADNER U: The potential of adiponectin in driving arthritis. J Immunol 176: 4468-4478, 2006.

FOJTÍKOVÁ M, TOMASOVÁ STUDÝNKOVÁ J, FILKOVÁ M, LACINOVÁ Z, GATTEROVÁ J, PAVELKA K, VENCOVSKÝ J, SENOLT L. Elevated prolactin levels in patients with rheumatoid arthritis: association with disease activity and structural damage. Clin Exp Rheumatol 28: 849-854, 2010.

KHARITONENKOV A, SHIYANOVA TL, KOESTER A, FORD AM, MICANOVIC R, GALBREATH EJ, SANDUSKY GE, HAMMOND LJ, MOYERS JS, OWENS RA, GROMADA J, BROZINICK JT, HAWKINS ED, WROBLEWSKI VJ, LI DS, MEHRBOD F, JASKUNAS SR, SHANAFELT AB: FGF-21 as a novel metabolic regulator. $J$ Clin Invest 115: 1627-1635, 2005.

KHARITONENKOV A, WROBLEWSKI VJ, KOESTER A, CHEN YF, CLUTINGER CK, TIGNO XT, HANSEN BC, SHANAFELT AB, ETGEN GJ: The metabolic state of diabetic monkeys is regulated by fibroblast growth factor-21. Endocrinology 148: 774-781, 2007.

KOTULAK T, DRAPALOVA J, KOPECKY P, LACINOVA Z, KRAMAR P, RIHA H, NETUKA I, MALY J, HOUSA D, BLAHA J, SVACINA S, HALUZIK M: Increased circulating and epicardial adipose tissue mRNA expression of fibroblast growth factor-21 after cardiac surgery: a possible role in postoperative inflammatory response and insulin resistance. Physiol Res 60: 757-767, 2011.

LIN Z, WU Z, YIN X, LIU Y, YAN X, LIN S, XIAO J, WANG X, FENG W, LI X: Serum levels of FGF-21 are increased in coronary heart disease patients and are independently associated with adverse lipid profile. PLoS One 5: e15534, 2010.

LIN Z, ZHOU Z, LIU Y, GONG Q, YAN X, XIAO J, WANG X, LIN S, FENG W, LI X: Circulating FGF21 levels are progressively increased from the early to end stages of chronic kidney diseases and are associated with renal function in Chinese. PLoS One 6: e18398, 2011.

MCCAREY D, STURROCK RD: Comparison of cardiovascular risk in ankylosing spondylitis and rheumatoid arthritis. Clin Exp Rheumatol 27 (Suppl 55): 124-126, 2009. 
MRAZ M, BARTLOVA M, LACINOVA Z, MICHALSKY D, KASALICKY M, HALUZIKOVA D, MATOULEK M, DOSTALOVA I, HUMENANSKA V, HALUZIK M: Serum concentrations and tissue expression of a novel endocrine regulator fibroblast growth factor-21 in patients with type 2 diabetes and obesity. Clin Endocrinol (Oxf) 71: 369-375, 2009.

NEUMANN E, FROMMER KW, VASILE M, MÜLLER-LADNER U: Adipocytokines as driving forces in rheumatoid arthritis and related inflammatory diseases? Arthritis Rheum 63: 1159-1169, 2011.

SCOTT DL, WOLFE F, HUIZINGA TW: Rheumatoid arthritis. Lancet 376: 1094-1108, 2010.

SENOLT L, HOUSA D, VERNEROVÁ Z, JIRÁSEK T, SVOBODOVÁ R, VEIGL D, ANDERLOVÁ K, MÜLLERLADNER U, PAVELKA K, HALUZÍK M: Resistin in rheumatoid arthritis synovial tissue, synovial fluid and serum. Ann Rheum Dis 66: 458-463, 2007.

SENOLT L, POLANSKÁ M, FILKOVÁ M, CEREZO LA, PAVELKA K, GAY S, HALUZÍK M, VENCOVSKY J: Vaspin and omentin: new adipokines differentially regulated at the site of inflammation in rheumatoid arthritis. Ann Rheum Dis 69: 1410-1411, 2010.

SENOLT L, KRYŠTŮFKOVÁ O, HULEJOVÁ H, KUKLOVÁ M, FILKOVÁ M, CEREZO LA, BĚLÁČEK J, HALUZÍK M, FOREJTOVÁ S, GAY S, PAVELKA K, VENCOVSKÝ J: The level of serum visfatin (PBEF) is associated with total number of B cells in patients with rheumatoid arthritis and decreases following $\mathrm{B}$ cell depletion therapy. Cytokine 55: 116-121, 2011a.

SENOLT L, KUKLOVÁ M, CEREZO LA, HULEJOVÁ H, FILKOVÁ M, BOSANSKÁ L, PECHA O, PAVELKA K, HALUZÍK M, VENCOVSKY J: Adipokine profile is modulated in subcutaneous adipose tissue by TNF \{alpha\} inhibitors in patients with rheumatoid arthritis. Ann Rheum Dis 70: 2054-2056, $2011 \mathrm{~b}$.

YILMAZ Y, EREN F, YONAL O, KURT R, AKTAS B, CELIKEL CA, OZDOGAN O, IMERYUZ N, KALAYCI C, AVSAR E: Increased serum FGF21 levels in patients with nonalcoholic fatty liver disease. Eur J Clin Invest 40: 887-892, 2010. 